\title{
Robert William Fogel remembrance
}

\section{A Celebration of the Life and Work of Robert William Fogel, Rockefeller Memorial Chapel, The University of Chicago, \\ October 4, 2013}

\section{Claudia Goldin}

(C) Springer-Verlag Berlin Heidelberg 2013

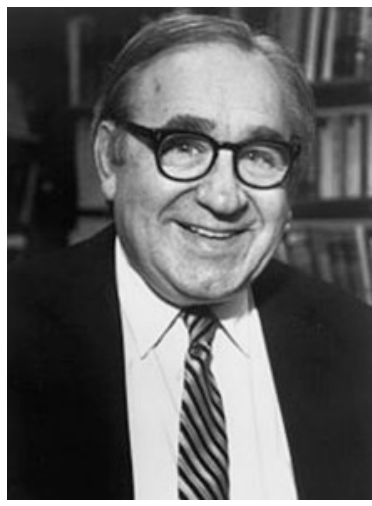

I first met Bob (I would have called him Mr. Fogel at the time) in 1968 when I took his graduate economic history course at the University of Chicago. ${ }^{1}$ He later became my main advisor on my PhD dissertation completed in 1972. In the late 1970s, we worked to create the DAE and I took over as its Program Director in 1989. I have known Bob all of my academic life. He shaped and encouraged it.

\footnotetext{
1 At the University of Chicago, faculty are not called professor and certainly not called doctor.

C. Goldin $(\bowtie)$

Henry Lee Professor of Economics, Harvard University, Cambridge, MA, USA e-mail: cgoldin@harvard.edu

C. Goldin

Director of the NBER's Development of the American Economy (DAE) Program, Cambridge, MA, USA
} 
When I think of Bob Fogel, I remember his many qualities: his generosity, his humanity, his brilliance, vision, humor, enthusiasm, and above all, his eternal optimism. But most of all, I think of the significance to him of FAMILY.

Family was very important to Bob. He had his personal family and he also had his created families of his students, research assistants, and staff.

Bob would tell each of his graduate students upon receiving their $\mathrm{PhD}$ to call him Bob. To use the "familiar." When he asked me to call him Bob, I responded, "Thank you, Mr. Fogel." Bob Fogel was too important, too special to be familiar. He was to be revered and looked up to. No child wants their father to be on equal standing. We eventually all called him Bob, but he would always be Mr. Fogel.

Family means nurturance and encouragement. For Bob, it meant telling a student their project was essential to a much larger idea. But after that initial encouragement, it also meant making certain it was done right.

I remember when Bob called me into his office to discuss my economic history graduate course paper on urban slavery. The paper was, for me, a course paper, a way to get a grade. But, for Bob, it had become a central part of his thinking about the ante-bellum southern economy. His vision of my work propelled me to write a longer essay. His continued encouragement led me to archives all over the South. And his eternal optimism got me to write a $\mathrm{PhD}$ dissertation and a book on the subject. But he also made certain that I did it right-and that I wrote it well and convincingly.

Family means protection from others. I recall in the 1980 s going to a DAE planning dinner (and there were many) in Cambridge one evening. I had made a tentative appointment to meet a guy (named Larry Katz) after the dinner. But Bob would not let me walk alone at night in "dangerous" (to him) Cambridgeport, and my date sort of evaporated. That is paternal protection.

Family means having meals together and sharing snacks. Bob had a refrigerator installed in Marilyn's office at 1737 Cambridge Street when he moved to Harvard in 1975. I subbed for him that year when he was in England and I got to stock the fridge with sprouts, carrots, and yogurt. Bob would return to Cambridge often that year to direct the construction of his home on Garden Street and his suite of offices. He would come straight from the airport to the office, tired and hungry, and would open the fridge expecting to find goodies. I would hear him mumbling, disgruntledly, "rabbit food." According to Bob, I had not stocked it properly. "People need lots of calories to work," he said, taking his research all too seriously. Did I not know, he continued, "that a significant portion of the French population in the eighteenth century was too undernourished to do anything more than beg?" Actually, I had stocked it properly and he knew it.

Family means making time to be with others, to schmooze and catch up. No matter how busy Bob seemed to be, he always engaged people personally first and intellectually second.

Family means extending kin networks across an ever expanding circle of members. I remember when Bob first introduced me to Stan Engerman, when Stan was heading off to archives where I had just been. Bob said: "call Stan on my nickel." I did call Stan and had so much fun talking with him that it must have amounted to many nickels. And I remember when Bob found out that I was going 
hiking in the Pacific Northwest. He decided that Doug North would enjoy having lunch with me and set it up. When Bob sent out invitations for Simon Kuznets' 80th birthday party I asked to be invited as Simon's intellectual "grandchild." It was a grand occasion and Simon appreciated my inclusion in the intellectual family.

Bob enjoyed the fact that he and I had many things in common. It made me "family by proximity." We are both from the Bronx; we both kept our Bronx accents (Bob more than I); we both went to selective public high schools (mine was the better one); we both went to Cornell University as undergraduates, and amazingly enough, we both studied at Cornell with the great IO economist Alfred Kahn.

And family meant to Bob, first and foremost, his own personal family. That family began with his parents Aaron and Elizabeth who came to the United States from Russia in 1923 with his brother Ephim. And that family was later centered on Enid, whom he called his "keenest critic" and the "overseer of [his] moral conscience." And that family then expanded with his children Michael and Steven and later his grandchildren and great-grandchildren. Bob always spoke with pride of his real family to his created family. He and Enid frequently invited the new family members to their home. I have fond memories of those events. It made us, the adopted, closer kin with Bob. 